УДК 636.22/28.081.14

\title{
ОСОБЛИВОСТІ РОЗВИТКУ РЕМОНТНИХ ТЕЛИЦЬ УКРАЇНСЬКИХ ЧЕРВОНО-РЯБОЇ ТА ЧОРНО-РЯБОЇ МОЛОЧНИХ ПОРІД У ГОСПОДАРСТВАХ СУМСЬКОГО РЕГІОНУ
}

\author{
Хмельничий Леонтій Михайлович \\ доктор сільськогосподарських наук, професор \\ Сумський національний аграрний університет \\ ORCID: 0000-0001-5175-1291 \\ Email: khmelnychy@ukr.net \\ Бардаш Дмитрій Олександрович \\ аспірант спеціальності 204-ТВППТ \\ Сумський національний аграрний університет \\ ORCID: 0000-0002-9368-2324 \\ Email: d.bardash@ukr.net
}

У провідних господарствах Сумського регіону вивчалися особливості росту ремонтних телиць українських чорнорябої (ПЗ ПП “Буринське”) та червоно-рябої (ТОВ «Млинівський комплекс») молочних порід. Досліджували абсолютні та відносні показники приростів живої маси телиць у віковій динаміці від народження до 18-ти місячного віку. Кращими за живою масою при народженні виявились телички української червоно-рябої молочної породи (36,2 ка) у порівнянні із ровеснииями української чорно-рябої молочної (33,9 кг). Їхня перевага збереглася упродовж 18-ти місячного періоду вирощування. Ремонтні телиці української червоно-рябої молочної породи на заключному етапі розвитку з середньою живою масою 414,2 к己 перевищували одноліток української чорно-рябої молочної з високодостовірною різницею на 15,5 к己 $(P<0,001)$. Розвиток ремонтних телиць обох порід у межах отриманих показників живої маси забезпечив їхній приріст на час парувального віку на рівні 76-80\% від мінімальних иільових стандартів, визначених на перспективу для корів-первісток молочного типу створених порід. Середньодобові прирости живої маси у молочний період склали у теличок української чорнорябої молочної породи в середньому 810,4 2, а у їхніх ровесниць української червоно-рябої - 847,3 г. Після шестимісячного періоду вирощування і до парувального віку різниця за середньодобовими приростами була вищою у тварин української червоно-рябої молочної породи стада ТОВ «Млинівський комплекс». Результати досліджень засвідчили, що за створення відповідних умов годівлі та утримання ремонтні телиці українських чорно-рябої та червоно-рябої молочних порід здатні до високої інтенсивності росту.

Ключові слова: українська чорно-ряба, українська червоно-ряба, ремонтні телиці, жива маса.

DOI: https://doi.org/10.32845/bsnau.lvst.2019.1-2.2

Поглиблена селекція молочної худоби неможлива без ретельної оцінки племінних тварин у ранньому віці та упродовж їхнього індивідуального розвитку. В цьому аспекті найпершим методом морфологічних досліджень розвитку тварин передбачають облік їхньої живої маси. Результатами цих спостережень $€$ показники росту тварин, які характеризують інтенсивність обмінних процесів, що відбуваються в організмі [7].

Як свідчить передовий практичний та науковий досвід інтенсивний ріст та розвиток ремонтних телиць молочної худоби істотним чином зумовлює бажаний тип будови тіла тварин у дорослому стані і, як результат, дозволяє максимально реалізувати генетичний потенціал молочної продуктивності корів детермінований спадковістю батьківських предків $[2,4,8,19,20,22]$.

Генетично запрограмована продуктивність може бути реалізована лише за сприятливих умов вирощування, догляду та використання тварин $[9,12,23]$. Встановлено, що інтенсивність росту телиць різних генотипів тісно пов'язана 3 рівнем молочної продуктивності. Зниження інтенсивності вирощування телиць у період до 18 місяців і першого отелення не дозволяє тваринам повністю реалізувати свій генетичний потенціал молочної продуктивності $[1,15]$.

3 виробничої точки зору скороспілість ремонтних телиць скорочує непродуктивний період вирощування від дня

народження до отелення, з селекційної - прискорює процес оцінки бугаїв-плідників за якістю потомства та сприяє інтенсивному відтворенню стада, що у підсумку істотно визначає рівень рентабельності молочного скотарства [6, 13]. Крім того, встановлено, що величина живої маси телиць на кінець періоду вирощування та початок парувального віку, позитивно корелює з послідуючою молочною продуктивністю за першу та інші лактації [3, 5, 17, 18, 25]. Отримані результати досліджень $[21,24]$ свідчать, що для визначення оптимального часу першого осіменіння більш важливе значення має не вік, а жива маса та загальний розвиток тварин, оскільки осіменіння телиць із низькою живою масою як в ранньому, так і в пізньому віці призводить до погіршення їх господарської цінності.

За даними досліджень [10] української червоної молочної породи встановлено, що корови реалізували свою найвищу молочну продуктивність за першу, третю та кращу лактації (6242, 7465 і 7916 кг молока відповідно) за умови їх першого осіменіння в 14,5-15-місячному віці та досягненні ними живої маси 420-439 кг.

Встановлено, що найвищий рівень молочної продуктивності корів-первісток (понад 8,0 тис. кг молока за 305 днів закінченої лактації) досягнуто у стадах, де середньодобовий приріст телиць у віковий період 0-12 міс. доведено до рівня 820-850 г. Дотримання вказаних параметрів $€$ передумовою 
формування високопродуктивних молочних стад, у яких нарощування ефективності виробництва молока буде забезпечено за рахунок скорочення непродуктивних витрат на утримання ремонтного молодняку і зростання чистого доходу від реалізації більших обсягів молока [11].

Метою досліджень було вивчення особливостей росту і розвитку ремонтних телиць українських молочних порід в умовах Сумського регіону.

Матеріали та методи досліджень. Експериментальною базою для проведення досліджень були стада підприємств з розведення української червоно-рябої молочної породи ТОВ «Млинівський комплекс» Роменської фрілії Сумської області та української чорно-рябої молочної породи племінного заводу ПП "Буринське” Підліснівського відділення Сумського району.

Динаміку живої маси телиць визначали за щомісячним зважуванням. Абсолютний приріст живої маси (D) за окремі вікові періоди дослідження визначали за формулою: маса, кг.

$\mathrm{D}=\mathrm{W}_{\mathrm{t}}-\mathrm{W}_{0}$; де $\mathrm{W}_{\mathrm{t}} \mathrm{i} \mathrm{W}_{\mathrm{o}}$ - кінцева і початкова жива

Абсолютний середньодобовий приріст визначали за формулою:

$$
\mathrm{D}=\frac{W t-W o}{t_{2}-t_{1}}
$$

де $\mathrm{W}_{\mathrm{t}}$ i $\mathrm{W}_{0}$ - жива маса в кінці і на початку періоду, кг; $t_{2}$ i t1 - вік в кінці і на початку періодів, днів.

Відносну інтенсивність росту (К) ремонтних телиць визначали за формулою С. Броді (цитовано за К.Б. Свечиным, [16]):

$$
K=\frac{(W t-W o) \times 100}{(W t+W o): 2}
$$

Статистичне опрацювання експериментальних даних проводили за формулами, наведеними Е.К. Меркурьевой [14] на ПК з використанням програмного забезпечення.

Результати досліджень. Оцінка ремонтних телиць піддослідних порід за приростами живої маси у віковій динаміці від народження до вісімнадцятимісячного віку свідчить про задовільні умови їхнього вирощування у підконтрольних господарствах, табл. 1.

Порівняльний аналіз результатів досліджень показав, що кращими за живою масою при народженні виявились телички української червоно-рябої молочної породи ТОВ «Млинівський комплекс» $(36,2$ кг) у порівнянні із ровесницями стада української чорно-рябої молочної породи ПП "Буринське" (33,9 кг) за високої достовірності різниці 2,3 кг $(P<0,001)$ на користь перших.

Упродовж 18-тимісячного періоду вирощування ремонтні телиці стада ТОВ «Млинівський комплекс» були істотно кращими у порівнянні із ровесницями стада ПП "Буринське". Вони на заключному етапі вирощування з середньою живою масою 414,2 кг перевищували одноліток 3 високодостовірною різницею на 15,5 кг ( $\mathrm{P}<0,001)$.

Розвиток у межах отриманих в процесі досліджень параметрів живої маси забезпечив ії̈ приріст у ремонтних телиць на час парувального віку на рівні 76-80\% від мінімальних цільових стандартів, визначених на перспективу для корів-первісток молочного типу створених порід (530-550 кг) [1].

Таблиця 1

Характеристика ремонтних телиць українських молочних порід

\begin{tabular}{|c|c|c|c|c|}
\hline \multirow{3}{*}{$\begin{array}{c}\text { Вік тварин, } \\
\text { місяців }\end{array}$} & \multicolumn{4}{|c|}{ Порода } \\
\hline & \multicolumn{2}{|c|}{ українська чорно-ряба молочна $(\mathrm{n}=22)$} & \multicolumn{2}{|c|}{ українська червоно-ряба молочна $(\mathrm{n}=24)$} \\
\hline & $\mathrm{X} \pm$ S.E., $\mathrm{K} \Gamma$ & $\mathrm{Cv}, \%$ & $\mathrm{X} \pm$ S.E., $\mathrm{k} \Gamma$ & $\mathrm{Cv}, \%$ \\
\hline Новонароджені & $33,9 \pm 0,14$ & 13,5 & $36,2 \pm 0,17$ & 12,3 \\
\hline 3 & $109,1 \pm 0,28$ & 14,2 & $118,7 \pm 0,48$ & 13,6 \\
\hline 6 & $181,4 \pm 0,69$ & 15,9 & $190,4 \pm 0,85$ & 14,2 \\
\hline 9 & $247,7 \pm 0,78$ & 14,7 & $254,7 \pm 1,05$ & 13,8 \\
\hline 12 & $298,8 \pm 1,04$ & 16,1 & $317,3 \pm 0,98$ & 15,7 \\
\hline 15 & $349,6 \pm 1,11$ & 15,2 & $368,2 \pm 1,14$ & 16,2 \\
\hline 18 & $398,7 \pm 1,29$ & 14,8 & $414,2 \pm 1,08$ & 15,5 \\
\hline Перше осіменіння & $414,8 \pm 1,67$ & 16,3 & $422,5 \pm 1,78$ & 17,2 \\
\hline Перше отелення & $537,4 \pm 1,68$ & 17,4 & $554,4 \pm 1,86$ & 16,8 \\
\hline
\end{tabular}
за живою масою у віковій динаміці

На період першого плідного осіменіння ремонтні телиці обох порід відповідали за живою масою параметрам бажаного типу з вищими результатами у тварин української червоно-рябої молочної породи стада ТОВ «Млинівський комплекс». Міжпородна різниця високодостовірна на користь останньої склала 7,7 кг (P<0,001). Аналогічна ситуація склалася у тварин у віці першого отелення з перевагою української червоно-рябої молочної породи на 17 кг $(\mathrm{P}<0,001)$.

В процесі вирощування ремонтних телиць молочної худоби варто враховувати межі інтенсивності їхнього вирощування, оскільки перевищений або недостатній рівень призводить зниження молочної продуктивності [25]. Рекомендовані нормативи середньодобових приростів за період вирощування до 18-місячного віку для одержання корів молочної худоби живою масою 500 кг становлять 650 г, а 600 кг, відповідно, - 700 г.
Інтенсивний розвиток телят в молочний період, який триває від народження до шестимісячного віку, має вирішальне значення. У цей період необхідно використати існуючу біологічну закономірність індивідуального розвитку, як висока енергія росту в перші місяці життя, що забезпечує одержання повноцінного молодняку. Середньодобові прирости живої маси у період від народження до шестимісячного віку склали у теличок української чорно-рябої молочної породи в середньому 810,4 г, а у їхніх ровесниць української червонорябої - 847,3 г (табл. 2). Різниця на користь останніх 36,9 г високодостовірна $(P<0,001)$.

Після шестимісячного періоду вирощування і до парувального віку різниця за середньодобовими приростами була вищою у тварин української червоно-рябої молочної породи стада ТОВ «Млинівський комплекс». 
Середньодобові прирости живої маси ремонтних телиць українських молочних порід

\begin{tabular}{|c|c|c|c|c|}
\hline \multirow{3}{*}{$\begin{array}{l}\text { Міжвіковий період, } \\
\text { місяців }\end{array}$} & \multicolumn{4}{|c|}{ Порода } \\
\hline & \multicolumn{2}{|c|}{ українська чорно-ряба молочна (n=22) } & \multicolumn{2}{|c|}{ українська червоно-ряба молочна $(\mathrm{n}=24)$} \\
\hline & $x \pm$ S.E., $\Gamma$ & $\mathrm{Cv}, \%$ & $x \pm$ S.E., $\Gamma$ & $\mathrm{Cv}, \%$ \\
\hline $0-3$ & $826,4 \pm 1,45$ & 11,2 & $906,6 \pm 1,18$ & 10,8 \\
\hline $4-6$ & $794,5 \pm 1,62$ & 12,1 & $787,9 \pm 1,22$ & 11,3 \\
\hline $7-9$ & $728,6 \pm 1,13$ & 10,8 & $706,6 \pm 1,35$ & 11,7 \\
\hline $10-12$ & $561,5 \pm 0,97$ & 9,5 & $687,9 \pm 1,08$ & 9,5 \\
\hline 13-15 & $558,2 \pm 0,88$ & 8,7 & $559,3 \pm 0,86$ & 8,4 \\
\hline $16-18$ & $539,6 \pm 0,91$ & 9,2 & $505,5 \pm 0,79$ & 7,8 \\
\hline $0-18$ & $665,7 \pm 0,84$ & 8,4 & $689,8 \pm 0,74$ & 7,5 \\
\hline
\end{tabular}

Отримані середньодобові прирости живої маси ремонтних телиць українських чорно- та червоно-рябої молочних порід за весь період вирощування, відповідно 665,7 та 689,8 г, забезпечили задовільну живу масу тварин як у віці першого осіменіння, так і першого отелення.

Абсолютний приріст певною мірою є показником інтенсивності росту тварин і ним широко користуються для контролю за ростом молодняку на різних етапах їхнього онтогенезу. Проте абсолютний приріст не може характе- ризувати порівняльний ступінь напруженості процесу росту тварин, оскільки він не відображає взаємин між величиною маси тіла тварини, що росте, та інтенсивністю їхнього приросту.

Для характеристики інтенсивності росту тварин нами були вивченні показники відносного приросту живої маси ремонтних телиць у трьохмісячній динаміці постнатального онтогенезу (табл. 3). При цьому встановлено незначну міжпородну мінливість за цією ознакою.

Таблиця 3

Відносний приріст ремонтних телець за живою масою, \%

\begin{tabular}{|c|c|c|c|c|}
\hline \multirow{3}{*}{$\begin{array}{l}\text { Міжвіковий період, } \\
\text { місяців }\end{array}$} & \multicolumn{4}{|c|}{ Порода } \\
\hline & \multicolumn{2}{|c|}{ українська чорно-ряба молочна (n=22) } & \multicolumn{2}{|c|}{ українська червоно-ряба молочна (n=24) } \\
\hline & $x \pm$ S.E. $\%$ & $\mathrm{Cv}, \%$ & $x \pm$ S.E., \% & $\mathrm{Cv}, \%$ \\
\hline $0-3$ & $105,2 \pm 1,32$ & 14,8 & $106,5 \pm 1,44$ & 15,1 \\
\hline $4-6$ & $49,8 \pm 1,84$ & 15,3 & $46,4 \pm 1,52$ & 15,9 \\
\hline $7-9$ & $30,9 \pm 2,11$ & 16,4 & $28,9 \pm 1,65$ & 16,4 \\
\hline $10-12$ & $18,7 \pm 2,18$ & 16,7 & $21,9 \pm 1,84$ & 17,2 \\
\hline $13-15$ & $15,7 \pm 2,24$ & 17,4 & $14,9 \pm 2,13$ & 18,6 \\
\hline $16-18$ & $13,1 \pm 2,88$ & 18,7 & $11,8 \pm 2,24$ & 19,8 \\
\hline
\end{tabular}

За повідомленням К.Б. Свечина [16], найбільш інтенсивним ростом характеризуються тварини у молочний період свого вирощування, а в подальшому цей процес сповільнюється. Показники відносного розвитку, які ми отримали у результаті досліджень, закономірно співпали із вищенаведеним твердженням.

Перевага телиць стада підприємства ТОВ «Млинівський комплекс» у порівнянні 3 однолітками племінного заводу ПП "Буринське" на початку періоду вирощування (від народження до 3 міс) становила з недостовірною різницею 1,3\%. В інші вікові періоди відносні показники між породами змінювалися, а на кінець періоду вирощування більш інтенсивно розвивалися телиці української чорно-рябої молочної породи.

Таким чином, результати експериментальних досліджень, одержаних у процесі вивчення росту та розвитку ремонтних телиць українських чорно- та червоно-рябої молочних порід, свідчать про їхню здатність за відповідних умов вирощування до високої інтенсивності росту.

Висновки. За створення відповідних умов вирощування ремонтні телиці українських чорно-рябої та червонорябої молочних порід здатні до високої інтенсивності росту, яка забезпечила одержання бажаного рівня живої маси на час першого осіменіння в середньому на рівні 414,8 та 422,5 Кг.

\section{Список використаної літератури:}

1. Буркат В.П., Мельник Ю.Ф., Єфіменко М.Я. та ін. Програми селекції порід. Розведення і генетика тварин. 2003. Вип. 37, С. 3-22.

2. Гиль М.І., Каратєєва О.І., Галушко І.А. Молочна продуктивність голштинських корів залежно від типу формування їх організму. «Молодий вчений». 2017. №5(45), С. 14-18.

3. Гордійчук Н.М., Півторак Я.І. Вплив живої маси теличок української червоно-рябої молочної породи при народженні на ріст і розвиток та молочну продуктивність. Збірник наукових праць Вінницького державного аграрного університету. 2008. Вип. 34. Т.3, С. 57-60.

4. Денисюк О.В. Вплив інтенсивності фрормування живої маси на молочну продуктивність корів. Розведення і генетика тварин. 2015. Вип. 49, С. 80-85

5. Заблудовський Є.Є., Голубчик Ю.І. Реалізація продуктивного потенціалу молочної худоби у зв'язку з особливостями росту. Розведення і генетика тварин.: матеріали наукової дискусії "Розведення сільськогосподарських тварин за лініями" : міжвідомчий тематичний науковий збірник ІРГТ. К. : Науковий світ, 2002. Вип. 36, С. 61-63.

6. Зубець М.В. Сірацький Й.3., Данилків Я.Н. Вирощування ремонтних телиць. К.: Урожай, 1993. 136 с.

Вісник Сумського національного аграрного університету 
7. Зубець М.В., Буркат В.П., Єфіменко М.Я. та ін. Генетико-селекційний моніторинг у молочному скотарстві. за ред. В.П. Бурката. К.: Аграрна наука, 1999. 88 с.

8. Ивашков А.И., Рыжкова Л.Ю. Особенности роста высокопродуктивных коров. Вестник Российского государственного аграрного заочного университета. 2006. № 1. (6), С. 121-122.

9. Икоева Л.П., Хаева О.Э. Выращивание ремонтных телок черно-пестрой породы разного генотипа по голштинской породе. Известия Горского государственного аграрного университета. 2014. Т. 51. №3, С. 133-141.

10. Ілляшенко Г.Д. Зв'язок молочної продуктивності корів з живою масою і віком при першому осіменінні. Розведення $і$ генетика тварин. 2017. Вип. 54, С. 45-50.

11. Кругляк О.В. Формування високопродуктивних молочних стад, як чинник підвищення ефективності виробництва молока. Економіка АПК. 2018. № 3, С. 24-31.

12. Кузів М.І. Ваговий та лінійний ріст телиць української чорно-рябої молочної породи в умовах західного регіону України. Вісник Сумського національного аграрного університету. 2013. №1, С. 40-43.

13. Маньковський А.Я. Молочна продуктивність первісток залежно від живої маси телиць та віку отелення. Науковий вісник національного університету біоресурсів і природокористування України. 2009. Вип. 138, С. 63-68.

14. Меркурьева Е.К. Генетические основы селекции в скотоводстве. М.: Колос, 1977. 240 с.

15. Підпала Т.В., Ясевін С.Є., Дровняк О.В. Інтенсивне вирощування ремонтного молодняку молочної худоби. Сучасні проблеми селекції, розведення та гігієни тварин. Збірник наукових праць ВНАУ. 2011. № 11 (51), С.117-120.

16. Свечин К.Б. Индивидуальное развитие сельскохозяйственных животных. К.: Урожай, 1976. - 288 с.

17. Сермягин А.А., Филипченко А.А., Ермилов А.Н., Янчуков И.Н. Параметры роста и развития коров черно-пёстрой и голштинской пород в связи с продуктивным долголетием. Дальневосточный аграрный вестник. 2018. №4 (48), С. $194-202$.

18. Скляренко Ю.И. Влияние интенсивности развития телочек на их дальнейшие хозяйственно-полезные признаки. Научно-технический бюллетень Института животноводства Национальной академии аграрных наук Украины. 2018. №119, С. 134-141.

19. Скляренко Ю.И., Чернявская Т.А., Иванкова И.П. Влияние интенсивности развития ремонтных телок украинской бурой молочной породы на продуктивность коров-первотелок. Интеграция науки и практики для развития Агропромышленного комплекса. Сборник статей Всероссийской научной конференции. 2017. С. 113-119.

20. Стадницька О.І. Вплив росту і розвитку корів у період вирощування на їх молочну продуктивність. Розведення $i$ генетика тварин. 2011. Вип. 45, С. 264-270.

21. Титаренко І.В., Буштрук М.В., Старостенко І.С. Вплив інтенсивності вирощування телиць на їх відтворну здатність та молочну продуктивність. Науково-технічний бюлетень НДЦ біобезпеки та екологічного контролю ресурсів АПК. 2016. Т.4, №1, C. 260-266.

22. Троценко 3.Г. Вплив темпів розвитку ремонтних телиць української чорно-рябої молочної породи на молочну продуктивність корів-первісток. Вісник Полтавської державної аграрної академії. 2010. №2, С. 79-81.

23. Хмельничий Л.М. Оцінка росту та розвитку телиць української червоно-рябої молочної породи за використання вагових та лінійних параметрів. Вісник Сумського національного аграрного університету. 2012. №12, С. 18-21.

24. Шевчук Б.И. Влияние выращивания телок в молозивно-профилакторный и молочный периоды на будущую молочную продуктивность коров-первотелок. Научно-технический бюллетень Института животноводства Национальной академии аграрных наук Украины. 2016. №116, С. 186-192.

25. Юшкова И.В., Петрова М.Ю., Князева Т.А. Параметры выращивания ремонтных телок внутрипородных типов в омской области. Генетика и разведение животных. 2015. № 2. С. 12-15.

\section{References:}

1. Burkat, V.P., Melnyk, Yu.F., Yefimenko, M.la, ta in. 2003. Prohramy selektsii porid. Rozvedennia i henetyka tvaryn [ Breeding programs]. Rozvedennia i henetyka tvaryn, issue 37, pp. 3-22.

2. Hyl, M.I., Karatieieva, O.I., and Halushko, I.A., 2017. Molochna produktyvnist holshtynskykh koriv zalezhno vid typu formuvannia yikh orhanizmu [Dairy performance of Holstein cows depending on the type of formation of their body]. "Molodyi vchenyi", issue 5 (45), pp. 14-18.

3. Hordiichuk, N.M., and Pivtorak, Ya.I., 2008. Vplyv zhyvoi masy telychok ukrainskoi chervono-riaboi molochnoi porody pry narodzhenni na rist i rozvytok ta molochnu produktyvnist [Influence of calfs live weight of Ukrainian Red-and-White dairy breed on growth and development and milk productivity]. Zbirnyk naukovykh prats Vinnytskoho derzhavnoho ahrarnoho universytetu, issue 34 , pp. 57-60.

4. Denysiuk, O.V., 2015. Vplyv intensyvnosti formuvannia zhyvoi masy na molochnu produktyvnist koriv [Impact intensity formation of live weight on milk production of cows]. Rozvedennia i henetyka tvaryn, issue 49, pp. 80-85.

5. Zabludovs'kyy, Ye.Ye., and Holubchyk, Yu.l., 2002. Realizatsiya produktyvnoho potentsialu molochnoyi khudoby u zv"yazku z osoblyvostyamy rostu [Implementation of the productive potential of dairy cattle due to peculiarity of the growth]. Rozvedennia i henetyka tvaryn.: materialy naukovoi dyskusii "Rozvedennia silskohospodarskykh tvaryn za liniiamy" : mizhvidomchyi tematychnyi naukovyi zbirnyk IRHT. K.: Naukovyi svit, issue 36, pp. 61-63.

6. Zubets, M.V., Siratskyi, Y.Z, and Danylkiv, Ya.N., 1993. Vyroshchuvannia remontnykh telyts [Growing of repair heifers], K.: Urozhai, pp. 136.

7. Zubets', M.V., Burkat, V.P., Yefimenko, M.Ya., ta in. za red. Burkata, V. P., 1999. Henetyko-selektsiynyy monitorynh u molochnomu skotarstvi [Genetics and breeding monitoring in Dairy cattle]. K.: Ahrarna nauka, pp. 88.

8. Ivashkov, A.I., and Ryzhkova, L.Yu., 2006. Osobennosti rosta vysokoproduktivnykh korov. Vestnik Rossiyskogo gosudar- 
stvennogo agrarnogo zaochnogo universiteta [Features of the growth of highly productive cows]. Vestnik Rossiyskogo gosudarstvennogo agrarnogo zaochnogo universiteta, issue 1(6), pp. 121-122.

9. Ikoeva, L.P., and Khaeva, O.E., 2014. Vyrashchivanie remontnykh telok cherno-pestroy porody raznogo genotipa po golshtinskoy porode [Growing repair heifers of Black-and-White breed of different genotype for Holstein breed]. Izvestiya Gorskogo gosudarstvennogo agrarnogo universiteta, issue 3, pp.133-141.

10. Illiashenko, H.D., 2017. Zviazok molochnoi produktyvnosti koriv z zhyvoiu masoiu i vikom pry pershomu osimeninni [Relation of dairy productivity of cows with live weight and age at first insemination]. Rozvedennia i henetyka tvaryn, issue 54, pp. 45-50.

11. Kruhliak, O.V., 2018. Formuvannia vysokoproduktyvnykh molochnykh stad yak chynnyk pidvyshchennia efektyvnosti vyrobnytstva moloka [Formation of high-performance dairy herds as a factor in improving milk production efficiency]. Ekonomika AПK, issue 3, pp. 24-31.

12. Kuziv, M.I., 2013. Vahovyi ta liniinyi rist telyts ukrainskoi chorno-riaboi molochnoi porody v umovakh zakhidnoho rehionu Ukrainy [Weight and linear growth heifers Ukrainian black-and-white dairy cattle in the western region of Ukraine]. Visnyk Sumskoho natsionalnoho ahrarnoho universytetu, issue 1, pp. 40-43.

13. Mankovskyi, A.la., 2009. Molochna produktyvnist pervistok zalezhno vid zhyvoi masy telyts ta viku otelennia [Firstborn dairy productivity depending on the live weight of calves and calving age]. Naukovyi visnyk natsionalnoho universytetu bioresursiv $i$ pryrodokorystuvannia Ukrainy, issue 138, pp. 63-68.

14. Merkur'eva, E. K. 1977. Geneticheskie osnovy selektsii v skotovodstve [Genetic Principles of selective breeding in cattle breeding]. Moscov: Kolos, pp. 240.

15. Pidpala, T.V., Yasevin, S.le., and Drovniak, O.V., 2011. Intensyvne vyroshchuvannia remontnoho molodniaku molochnoi khudoby. Suchasni problemy selektsii, rozvedennia ta hihiieny tvaryn [Intensive cultivation of dairy cattle repair young. Modern problems of selection, breeding and hygiene of animals]. Suchasni problemy selektsii, rozvedennia ta hihiieny tvaryn. Zbirnyk naukovykh prats VNAU, issue 11(51), pp.117-120.

16. Svechin, K.B., 1976. Individual'noe razvitie sel'skokhozyaystvennykh zhivotnykh [Individual development of farm animals]. K.: Urozhay, pp. 288.

17. Sermyagin, A.A., Filipchenko, A.A., Ermilov, A.N., and Yanchukov, I.N., 2018. Parametry rosta i razvitiya korov chernopestroy i golshtinskoy porod v svyazi s produktivnym dolgoletiem [Parameters of growth and development of cows of black-and-white and Holstein breeds in connection with productive longevity]. Dal'nevostochnyy agrarnyy vestnik, issue 4(48), pp. $194-202$.

18. Sklyarenko, Yu.I., 2018. Vliyanie intensivnosti razvitiya telochek na ikh dal'neyshie khozyaystvenno-poleznye priznaki [Influence of intensity development of calfs on their further economically useful features]. Nauchno-tekhnicheskiy byulleten' Instituta zhivotnovodstva Natsional'noy akademii agrarnykh nauk Ukrainy, issue 119, pp. 134-141.

19. Sklyarenko, Yu.I., Chernyavskaya, T.A., and Ivankova, I.P., 2017. Vliyanie intensivnosti razvitiya remontnykh telok ukrainskoy buroy molochnoy porody na produktivnost' korov-pervotelok [The influence of the intensity of development of repair heifers of Ukrainian brown milk breed on the productivity of first-calf cows. Integration of science and practice for development of agroindustrial complex]. Sbornik statey Vserossiyskoy nauchnoy konferentsii, pp. 113-119.

20. Stadnytska, O.I., 2011. Vplyv rostu i rozvytku koriv u period vyroshchuvannia na yikh molochnu produktyvnist [Influence of growth and development of cows during the growing period on their milk productivity]. Rozvedennia $i$ henetyka tvaryn, issue 45 , pp. 264-270.

21. Tytarenko, I.V., Bushtruk, M.V., and Starostenko, I.S., 2016. Vplyv intensyvnosti vyroshchuvannia telyts na yikh vidtvornu zdatnist ta molochnu produktyvnist [Influence of calf rearing intensity on their reproductive capacity and milk productivity]. Naukovotekhnichnyi biuleten NDTs biobezpeky ta ekolohichnoho kontroliu resursiv APK, issue 1, pp. 260-266

22. Trotsenko, Z.H., 2010. Vplyv tempiv rozvytku remontnykh telyts' ukrayins'koyi chorno-ryaboyi molochnoyi porody na molochnu produktyvnist' koriv-pervistok [The influence of rate of development of repair heifers of Ukrainian Black-and-White Dairy breed on milk production of firstborn]. Visnyk Poltavskoi derzhavnoi ahrarnoi akademii, issue 2, pp. 79-81.

23. Khmel'nychyi, L.M., 2012. Otsinka rostu ta rozvytku telyts' ukrayins'koyi chervono-ryaboyi molochnoyi porody za vykorystannya vahovykh ta liniynykh parametriv [Estimation of the growth and development of heifers Ukrainian Red-and-White dairy breed by using weight and linear parameters]. Visnyk Sumskoho natsionalnoho ahrarnoho universytetu, issue 12(21), pp. 18-21

24. Shevchuk, B.I., 2016. Vliyanie vyrashchivaniya telok v molozivno-profilaktornyy i molochnyy periody na budushchuyu molochnuyu produktivnost' korov-pervotelok [The effect of growing heifers in colostrum and dairy periods on the future milk production of cows firstborn]. Nauchno-tekhnicheskiy byulleten' Instituta zhivotnovodstva Natsional'noy akademii agrarnykh nauk Ukrainy, issue 116, pp. 186-192.

25. Yushkova, I.V., Petrova, M.Yu., and Knyazeva, T.A., 2015. Parametry vyrashchivaniya remontnykh telok vnutriporodnykh tipov v omskoy oblasti [Parameters of growing repair heifers of intrabreed types in the Omsk region]. Rozvedennia i henetyka tvaryn, issue 2, pp. 12-15.

Khmelnychyi, L.M.

Bardash, D.O.

Features of development repair heifers Ukrainian Red-and-White and Black-and-White dairy breeds in the farms of Sumy region

In Sumy region's leading farms have been studied the growth features of repair heifers Ukrainian Black-and-White (PE "Burynske") and Red-and-White (LLC "Mlyniv complex") dairy breeds. The absolute and relative growth rates of live weight of heifers in age dynamics from birth to 18 months of age were investigated. Best of body weight at birth appeared heifers of Ukrainian Red- 
and-White dairy breed (36.2 kg) compared to peers Ukrainian Black-and-White dairy breed (33.9 kg). Their advantage was preserved during the 18-month period of growth. Repair heifers Ukrainian Red-and-White dairy breed at the final stage of development with average live weight $414.2 \mathrm{~kg}$ exceeded peers Ukrainian Black-and-White dairy with highly reliable difference on $15.5 \mathrm{~kg}(P$ <0.001). The development of both breeds repair heifers within the obtained parameters of live weight provided their gain during the mating age at the level of $76-80 \%$ of the minimum target standards set on the long-term for cows firstborn of dairy type created breeds. The average daily live weight gain in the dairy period amounted to $810.4 \mathrm{~g}$ at heifers of Ukrainian Black-and-White dairy breed, and $847.3 \mathrm{~g}$ in their peers of Ukrainian Red-and-White breed. After a six-month growing period and up to the mating age, the difference in average daily increments was higher in animals of Ukrainian Red-and-White dairy breed herd of LLC "Mlyniv complex". The results of research have shown that under the creation of appropriate conditions for feeding and keeping, the repair heifers of Ukrainian Black-and-White and Red-and-White dairy breeds are capable to high-intensity growth rates.

Key words: Ukrainian Black-and-White, Ukrainian Red-and-White, repair heifers, live weight.

Дата надходження до редакції: 15.02.2019 р. 